\title{
Introducing Herbicide Resistant Crops to Sri Lanka: A Review
}

\author{
Shyama R. Weerakoon* \\ Department of Botany, The Open University of Sri Lanka
}

\begin{abstract}
Over the last three decades substantial effort has been made to breed herbicide resistant crops (HRCs) and introduce them as a measure to relieve the constraints imposed by different combinations of chemicals, solving problems associated with herbicide residues, expansion of the range of compounds available, simplify crop management and extending the useful life of currently utilizing herbicides. A limited number of HRCs have been commercialized in the last three decades and a majority of these crops are cultivated in developed countries. Although evidences support that farmers can benefit from HRCs, there are many concerns about the health risks and environmental impacts related to HRCs. As an agriculturally based developing country, introduction of HRCs and their impacts could be an important issue to Sri Lanka. The farmer's main concern is to produce as much crop as possible with a high yield to meet the consumer demand. Therefore, the national level institutional capacity, scientific infra-structure and financial support need to be expanded for the development of country's own biotechnological programs to produce new crop cultivars. Further, focus is a need in comprehensive studies to fully assess the potential benefits and adverse consequences of introducing HRCs in Sri Lanka. Thus, the best alternatives would be to look for naturally accessible HRC germplasms, crop rotation, and sustainable farming practices including sustainable herbicide utilization to compete with weeds.
\end{abstract}

Keywords: Bio-pollution, Herbicide resistant crops, Sri Lanka, Weeds

\section{Introduction}

Limitation of land resources and ever growing human population demand a rapid increase in the crop production to fulfil the food demand and security to feed the population. The emergence of weeds in cropping system becomes a major challenge to the increasing crop productivity.

*Correspondence should be addressed to Prof. Shyama R Weerakoon, Dept. of Botany, Faculty of Natural Scineces, The Open University of Sri Lanka, (email: shyamaweerakoon@gmail.com) 
Weeds are not only competing with crop plants affecting yield quantity and quality but also obstruct harvesting efficiency and contribute to the persistence and spread of pests and diseases. Since the Second World War chemical herbicides have largely replaced labour intensive cultural regimes in weed control (Duke, 1996). Herbicides fall into two categories. Selective herbicides have been specially developed for particular crops that have natural tolerance to them. Non-selective (also referred to as broadspectrum) herbicides are effective against virtually all plants that can, therefore, only be used in special circumstances where they do not contact the crop (Duke, 1996).

The use of synthetic herbicides in agriculture flourished with the arrival of selective, auxinic herbicides (e.g. 2, 4-D) in the middle of the last century. Since then, herbicide manufacturers have attempted to develop herbicides that would kill more or all of the problematic weeds without damaging the crop. Over the last half of the $20^{\text {th }}$ century, many classes of selective herbicides with a varing of modes of action were discovered and developed. During the development of herbicides, herbicide molecules were tailored to provide greater selectivity, efficiency and safety. Some exceptional non-selective herbicides such as paraquat, glufosinate and glyphosate were also developed.

Though the herbicide development culminated in the past, herbicide-resistant weeds have been discovered in early 1970s. This discovery triggered an interest on developing herbicide resistant crops using crop breeding techniques. Advancement of molecular genetics made it possible to incorporate herbicide resistant genes from unrelated organisms into a susceptible crop.

Over the last three decades, considerable effort has been made to breed herbicide resistant crops (HRCs) and it was expected to relieve the constraints imposed by different combinations of chemicals, overcome problems associated with herbicide residues, expand the range of compounds available for selective use in-crop, simplify crop management and extend the useful life of current non-selective herbicides (Senior \& Bavage, 2003).

Proceeding to the advent of modern biotechnology, there was a limited effort to find or breed cultivars that were resistant to particular herbicides. Shortly after the first weeds evolved resistance to herbicides, scientists began to consider altering crops to make them resistant to herbicides. Initially, non- 
transgenic methods were used. A breeding program was initiated to move resistance from Brassica rapa L., that evolved resistance to triazine herbicides to other Brassica spp. crops (Hall et al., 1996). This approach was used to produce several triazine resistant canola varieties, which were released in 1980s. A number of HRCs were commercially grown since 1984 during which the first triazine-resistant oilseed rape cultivar (OAC Triton) was introduced to the Canadian market (Hall et al., 1996). However, no other triazine resistant crops were developed. Since then other non-transgenic methods such as whole-cell selection, mutagenesis and plant selection from natural populations have been used to produce sulfonylurea-resistant soybeans, sethoxydim-resistant maize and several imidazolinone-resistant crops (Green \& Owen, 2011).

In the early 1980s, the tools for producing transgenic crops became available. This technology was used to produce crops resistant to a very broad spectrum of herbicides such as glyphosate and glufosinate. Thus, HRCs were the first commercialized transgenic crops. Another early HR transgenic crop available to farmers was bromoxynil-resistant cotton in 1995 (Stalker et al., 1996). A transgene encoding a plasmid-encoded nitrilase from Klebseilla ozaenae was used to generate plants that rapidly degrade bromoxynil to non-toxic benzoic acid derivatives of bromoxynil. Additionally, transgenic bromoxynil-resistant canola was introduced in 2000. None of these bromoxynil-resistant HRCs constitute a significant market share (Duke, 2005). However, they have been very useful when the weed pressure from bromoxynilsusceptible weeds was a problem. Since bromoxynil was not a broad-spectrum herbicide, introduction of these HRCs simply added another selective herbicide to those already available for use on these crops.

Introduction of transgenic crops that are resistant to a broadspectrum of herbicides allowed the use of non-selective herbicides in weed management. The two mostly used non-selective herbicides in transgenic crops are glyphosate and glufosinate. Both of these herbicides have molecular targets in amino acid biosynthesis pathways. At present, most of the widely planted HRCs are glyphosate-resistant. Among these crops, glyphosateresistant soybean and canola were introduced in 1996, cotton in 1997, and maize in 1999 (Duke, 2005). HRCs were first produced using the traditional breeding methods, whereas a large number of currently used HRCs have been produced by application of genetic 
engineering. This technology has unintentionally positioned these crops in a hostile debate on the introduction and commercial use of genetically modified (GM) crops (Duke, 2005).

Although GM crops are being grown in an area of over 50 million ha., only a limited number of HRCs have been commercialized for the last two decades (Table 1) including rice, soybean, wheat, canola, cotton, sugar beet and sunflower (Green \& Owen, 2011). A major contributing factor in this regard is the pressure exerted by certain groups on major food companies to reject products derived from GM crops, and the risk of reduced sales if they do not do so. In addition, misinformation concerning regulatory requirements and product safety testing has also had a negative effect on public confidence in the technology. Scientists have also employed a wide range of non-transgenic techniques to create crops with resistance to a number of herbicides (Table 1). For instance, the first commercial ACCase-resistant crop was a sethoxydim-resistant (SR) corn with an altered ACCase created using tissue culture selection (Somers, 1996). A second ACCase trait is in the final stages of commercialization for use in sorghum. This trait was transferred with traditional breeding methods from feral sorghum (shattercane, Sorghum bicolor L. Moench) that had evolved ACCase herbicide resistance because of agronomic practices. (Tuinstra, 2008).

As far as Sri Lanka is concerned, the literature on the HRCs in Sri Lanka is inadequate and limited work is reported for naturally occurring herbicide resistance in crops. However, glyphosate resistance in rice was reported for ten inbred-cultivated rice varieties (Bg250, Bg94-1, Bg304, Bg359, Bg406, Bg379-2, Bg366, $\mathrm{Bg} 300, \mathrm{Bw} 364$, and At362) and three traditional rice varieties ("Kalu Heenati", "Sudu Heenati", "Pachchaperumal" (Weerakoon et al., 2013a). Therefore, the scarcity of literature on HRCs in Sri Lanka indicates that there is a need of prioritising studies related to HR. Initiation of such studies should emerge through the involvement of government organizations. 
Table 1. Summary of Transgenic and Nontransgenic HerbicideResistant Crops (Green \& Owen, 2011)

Crop Herbicide(s)

\section{Transgenic Herbicide Resistant Crops}

Cotton

Glyphosate, Glufosinate, Bromoxynil

Corn

Glyphosate, Glufosinate

Soybean

Glyphosate, Glufosinate

\section{Non-Transgenic Herbicide Resistant Crops}

Canola

Wheat

Soybean

Rice

Corn

Sugarbeet

Alfalfa

Sunflower
Triazine, Bromoxynil, Imidazolinones, Glyphosate, Glufosinate

Terburryne, Imidazolinone

Sulfonylurea, Atrazine, Glyphosate

Imidazolinone

Imidazolinone, Sethoxydim

Imidazolinone, Glyphosate

Glyphosate

Imidazolinone

\section{Developing Herbicide Resistant Crops}

It is increasingly difficult to discover a new herbicide and even more difficult to find one with a novel mode of action. At present, approximately 500,000 compounds need to be screened to discover a potential herbicide compared with one per 500 compounds screened in the 1940s. Since then there are difficulties in discovering new herbicides, expanding the utility of existing herbicides that have a broad weed-control spectrum and good environmental profile. Biotechnology approach is a useful 
strategy for advancing the development of selective herbicides (Tan et al., 2005; Devine, 2005). There are basically four means of developing herbicide resistant plants.

Breeders have been involved in modifying the genetic make-up of plants through conventional breeding methods for a long period. They have developed new crop varieties using the existing genetic variability or by creating new variability, which is the prerequisite for any breeding programme. Conventional breeding of herbicide resistant plants were developed as a result of sexual hybridization, backcrossing and pedigree breeding techniques. The first licensed atrazine tolerant canola (Brassica napus L.) cultivar "OAC Triton" became available in 1981. This was developed by conventional breeding techniques as a result of sexual hybridization and backcrossing with $B$. rapa L. (Bird's rape) that had evolved tolerance to the herbicides (Senior \& Bavage, 2003).

Plant genetic transformation is the science of direct gene transfer and integration, from one plant to another or from a microorganism to a plant, to create plants with altered genetic make-ups to achieve specific crop production goals. The altered plants are generally termed transgenic (or genetically modifiedGM). A number of GM crops expressing various traits have been commercialized and several others are at various stages of development (Tsaftaris, 1996). Until today, HR transgenic crops have been the most widely used type of transgenic crops. In 2008, worldwide, $63 \%$ of all agricultural land devoted to transgenic crops involved HR transgenic ones, and the percentage was higher (85\%) when the herbicide-tolerant trait was stacked with another (Bonny, 2009). Transgenesis for herbicide resistance involves the identification of an herbicide resistant gene from a plant or microorganism, its isolation and manipulation for efficient plant expression (if it is of microbial origin) and its subsequent delivery, stable integration and expression in the cells of the target crop plant. For the most part, a gene coding for useful HR in crops is isolated from herbicide degrading soil microorganisms (James, 2003).

A number of techniques are now available for the transfer of genes (genetic engineering) into crop plants, including Agrobacteriummediated gene transfer, micro-projectile (or particle) bombardment, polyethylene glycol-mediated DNA transfer and cell (protoplast) electroporation. The most commonly employed techniques in developing HRCs are the Agrobacterium and the 
particle bombardment methods. Herbicide resistance via genetic transformation can be conferred by one of the following methods (Mulwa \& Mwanza, 2006):

1. Introduction of a gene(s) coding for a herbicide detoxifying enzyme(s); and

2. Introduction of gene(s) coding for a herbicide insensitive form of a normal functioning enzyme or over expression of the genes coding for a herbicide target enzyme such that the normal metabolic functioning is still achieved in the plant even though some of the enzyme is inhibited.

At present, only five transgenes have been used in commercial crops to confer resistance to herbicides. Agrobacterium sp. strain CP4 which encodes5-enolpyruvyl-shikimate-3-phosphate synthase (EPSPS), GOX (glyphosate oxidorreductase), GAT (glyphosate acetyl-transferase) and the mutated maize EPSPS genes which have been used for glyphosate resistance, the gene encoding a nitrilase for bromoxynil resistance, and the bar gene for glufosinate resistance. Several glyphosate-resistant crops such as soybean, cotton, canola etc. were developed by introgresssing the CP4 gene from Agrobacterium sp., which encodes a resistant form of EPSPS (Padgette et al., 1996). The glyphosate-resistant canola also contains a gene that encodes GOX from the microbe Ochrobacterium anthropi (strain LBAA). Glyphosate oxidorreductase degrades glyphosate to glyoxylate and aminomethylphosphonate (AMPA), a non-toxic compound. The bar gene from Streptomyces hygroscopicus makes plants resistant to glufosinate by inactivating this herbicide through acylation (Reddy et al., 2004). Many crop species such as corn,cotton, canola, have been successfully transformed with this gene.

Chemical or physical mutagenesis of seed, microspores or pollen followed by selection under herbicide selective pressure has also been utilized to develop resistance to herbicides in crops. Mutagenic agents such as nitroso ethyl urea (NEU), nitroso methyl urea (NMU) and ethyl methane sulphonate (EMS) are potential inducers of mutations in chloroplast DNA (Venkataiah et al., 2005). The most common method of mutagenesis includes the use of EMS (McCabe et al., 1990). In this method, seeds or pollen are treated with EMS then grown either in vitro or in vivo in the presence of a herbicide. Surviving plants are selected and grown to maturity to provide seed that is used for further screening with herbicides. Utilizing this method, Sandhu et al. (2002) developed 
21 Brazilian rice lines that were resistant to glyphosate. AshfaqFarooqui et al. (1997) produced atrazine resistant Solanum melongena plants by mutagenizing seeds followed by germination and in vitro regeneration of plants from the resultant seedling cotyledons.

Ultra-violet (UV) or EMS treated microspores or pollen can be grown in vitro into haploid plantlets whose chromosome number can be doubled to create instant inbred lines bearing a specific herbicide tolerant trait. Ahmad et al. (1991) used microspore UV mutagenesis and haploid culture to develop canola plants that were resistant to chlorsulfuron. Imidazolinone tolerance in oilseed rape has been obtained by microspore mutagenesis (Mulwa \& Mwanza, 2006). This approach relied upon somoclonal variation in the culturing of pollen, which gave rise to mutant haploid plants that could be chemically induced to double their chromosomes to form homozygous mutant cultivars.

Imidazolinone-resistant rice was developed through chemically induced seed mutagenesis with EMS (Gealy et al., 2003; Tan et al., 2005). Further, IMI rice ("Clearfield") was engineered through mutation by radioactive bombardment to tolerate imidazolinone herbicides and IMI rice has been adopted for its use in USA, Costa Rica, Colombia and Uruguay (Annou et al., 2001). In Sri Lanka, attempts were made to induce and enhance naturally existing glyphosate resistance in traditionally cultivated and inbred cultivated rice varieties using induced seed mutagenesis with $\mathrm{NaN}_{3}$ (Sodiun azide) and EMS (Weerakoon et al, 2013b). According to the findings $\mathrm{NaN}_{3}$-treatment enhanced naturally existing $\mathrm{HR}$ in four inbred and one traditional rice varieties and induced HR in two susceptible rice varieties. EMS-treatment induced HR in five inbred rice varieties and two traditional rice varieties. Further, EMS enhanced naturally existing HR in three inbred and one traditional rice variety. Similarly, metribuzin tolerance in narrowleafed lupin (Lupinus angustifolius) has been obtained by treating seeds with $\mathrm{NaN}_{3}$ (Si et al., 2009). However, none of the HR lupin varieties have been commercialized so far.

Plant tissue culture represents the simplest of the biotechnologies available to plant scientists today. The plants, which are produced by culturing tissues, are tested for their sensitivity to a particular herbicide. This procedure is repeated preferably with increasing amounts of said herbicide to provide a herbicidetolerant/resistant strain of plant tissue which is subsequently 
subjected to differentiating growth conditions to provide herbicidetolerant plants. These plants can be propagated vegetatively using tissue culture methods to produce additional plants of the same genetic constitution. The plants also can be sexually reproduced to provide seeds and plants, which display inherited tolerance to the said herbicide (Mulwa \& Mwanza, 2006).

Cell culture under lethal concentrations of certain herbicides also results in gene amplification in surviving cells that leads to resistance through the overproduction of enzymes targeted by herbicides. A carrot cell line with resistance to glyphosate was selected in this manner and subsequently plants were regenerated that were resistant to the sulfonylurea herbicide, chlorsulfuron (Caretto et al., 1994). In vitro development of phosphinothricin (PPT) resistant rice has also been reported by inducing plantlet regeneration in explants collected from 7-day old seedlings on medium supplemented with sublethal doses of PPT (Toldi et al., 2000). Other in vitro cell selection studies have resulted in the development of resistance to paraquat in tomato cells (Thomas \& Pratt, 1982), resistance to glyphosate in carrot and groundnut cells (Murata et al., 1998; Jain et al., 1999) and resistance to a Protoporphyrinogen oxidase (PPO) inhibitor in soybean cells (Warabi et al., 2001).

\section{The Benefits of Herbicide Resistant Crops}

There are growing evidences that HRCs provide significant benefit to farmers (Devine \& Buth, 2001). Farmers benefit from the excellent broad-spectrum weed control provided by such herbicides and from substantially lower costs of growing some HRCs. These factors have encouraged the adoption of HR corn, soybean and cotton in the USA and HR canola in Canada (James, 2003). HRCs provide additional crop choice, enabling implementation of alternate weed management tactics to target specific weeds while maintaining crop sequences. Therefore, it is believed that inclusion of an HR crop in a cropping program along with a range of weed management tactics can ensure to control hard-to-control weeds (Beckie et al., 2006). Triazine tolerant canola has been used as an effective break crop in paddocks infested with wild radish, whereas conventional canola, faba beans, chickpeas and lentil are not viable choices in these paddocks, thereby limiting the number of available break crops (Devine \& Buth, 2001). 
Although there is a great concern among the general public, studies suggest that the use rate (unit weight per unit area) of herbicides in HRCs is not substantially different from that in conventional crops (Duke, 2005). The two main herbicides used in HRCs, glyphosate (Roundup) and glufosinate (Basta) have relatively short soil half-lives, and neither moves easily to ground or surface water (Duke et al., 2003). Although there is concern about the possible effects of HRCs on soil health, there is no evidence that currently released HR crops cause significant direct effects on stimulating or suppressing soil nutrient transformation in field environments (Motavalli et al., 2004).

As far as GM organisms are concerned, most regulatory systems only consider indirectly on the issue of whether or not the GM products are useful. According to European regulation $(2001 / 18 / \mathrm{EC})$ it is totally assumed that if a product is commercially viable it is useful. However, an alternative definition to usefulness could be that the product must fulfil important community needs (Madsen et al. 2002a). HRCs have mainly been developed to benefit farm-management, whereas benefits to consumers are less apparent. The general advantages appear to be linked with the fact that HRCs enable farmers to employ a flexible and easy management strategy. For some HRCs, it is possible to replace herbicides with a less favourable environmental profile. Some crops (cotton and canola) have led to significantly decrease $(13 \%)$ the usage of herbicide, measured as active ingredient applied per hectare. It has been reported that HRCs allowed lowering the herbicide usage by 14\% reduction worldwide (Brooks \& Barfoot, 2007).

Glyphosate-resistant soybean has been adopted mainly because it simplifies weed control to the use of a single herbicide and with a more flexible timing than that required for conventional herbicides. Because, glyphosate is strongly adsorbed to the soil thus, there is a negligible threat of residual effects on subsequent rotational crops. The number of herbicide applications in soybeans is estimated to have dropped by $12 \%$, between 1995 and 1999. However, when this is measured in terms of the total amount of active ingredients used, there seems to be an increase. Increasing herbicide use in soybean in the United States could partly be explained by the increased area sown with this crop (Carpenter \& Giannessi, 2001). The American Soybean Association states that glyphosate-resistant soybean protects the environment 
through changes in tillage practices and herbicide application, and also by improved weed control (Anderson, 2001).

Similarly, HR-rice varieties (IMI rice or "Clearfield") are now commercially available (Annou et al., 2001). From an agronomic viewpoint, two main reasons are frequently put forward to justify the development and introduction of HR-rice. The first reason is to improve control of the weed flora (especially red rice and other weedy rice species) associated with this crop, (Olofsdotter et al. 2000; Gealy and Dilday, 1997). The second reason is to provide an alternative tool for the management of weeds that have already evolved resistance to particular herbicides, especially grasses such as Echinochloa spp. (Olofsdotter et al. 2000; Wilcut et al. 1996). HR-rice, furthermore, allows for the substitution of some of the currently used herbicides by others less detrimental to the environment (Olofsdotter et al. 2000). In many areas in the world, soil erosion due to tillage practices is a problem. In general, HRCs may be favourable to the environment by allowing for flexible weed management compared to conventional systems. This may allow farmers to practice conservation tillage, e.g. no-till or reduced tillage, and thereby reduce soil erosion (Duke, 2005). A wide collection of other combinations of current and new herbicide resistance traits is expected within the next decade. If used correctly, these multiple HRCs will provide new uses for existing herbicides to help growers better manage weeds. By using diverse weed management practices, growers will preserve the utility of herbicide resistance traits and herbicide technologies and help maintain profitable and environmentally sustainable crop production systems for future generations (Green $\&$ Owen, 2011).

The dose-response curves also could be used to evaluate the effectiveness of HRCs. The dose-response relationship for a particular combination of herbicide and plant species under specific growth stage and climatic conditions could be described as in Figure 1. Figure 1.A illustrates a non-selective herbicide and the desired control level for the weed and Figure 1.B shows what happens when the crop in Figure 1.A is made tolerant to an otherwise non-selective herbicide 

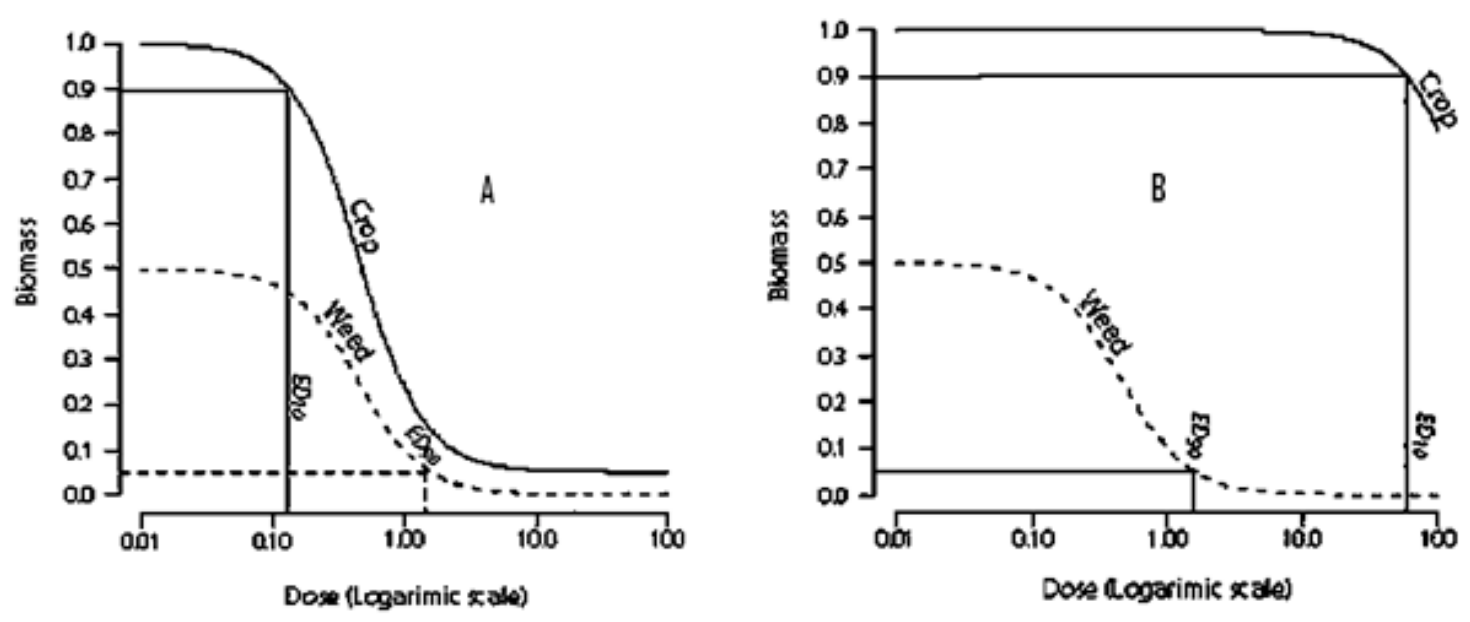

Figure 1. Dose response curves (Madsen et al., 2000)

A. Non-selective herbicide, both weed and crops are susceptible

B. The crop in A has been made tolerant to the herbicide giving a very high index of selectivity

\section{The Risks and Environmental Impacts}

The risks of HRCs can be estimated qualitatively on the possibility and severity of immediate and delayed adverse effects to human health, environment and farmer's economy. The possibility and severity of each unwanted effect associated with HRCs depends on the crop, the HR trait, the local weed flora, climatic conditions and farm management practices and is possible to estimate on a caseby-case basis (Madsen et al. 2002b).

The optimal weed control in glyphosate-resistant crops, often requires sequential applications with glyphosate, and the timing relative to weed emergence (Swanton et al. 2000). When glyphosate is sprayed 2-3 times annually at high rates, it imposes a high selection pressure on weeds. In 5-8 years this could cause shifts in weed composition towards species that naturally tolerate glyphosate (Benbrook, 2001; Shaner, 2000). Then other herbicides may be needed to control these herbicide tolerant weeds (Shaner, 2000). 
Increased herbicide use is considered as a risk worldwide. There are suspicions that herbicide use will increase as a result of HRCs. Two major explanations could be given why herbicide use in HRCs may increase. One reason is that a high level of crop tolerance can enable the farmer to increase doses to achieve an improved weed control without harming the crop. The other reason is the establishment of tolerant/resistant weeds and volunteers, which require farmers to increase dose or mix herbicides with different modes of action to maintain an acceptable level of weed control.

In addition, biodiversity within the field could be influenced if the herbicide, to which the HRC, is resistant. Furthermore, weed species respond differently to different herbicides or other weedcontrol measures and a shift in prevailing species is very likely. If an HRC is growing in a centre of genetic origin, then changes in the diversity of the indigenous species and risks of diminishing the genetic diversity of these species is a hazard (FAO, 2001). It is, however, very unlikely that HRCs will cause erosion of genetic diversity of wild species outside the cultivated land. Because the trait is associated with the use of herbicides which are not being applied in the wild, and a HR trait does not confer selective advantage unless the herbicide is used (Madsen et al. 1998). Therefore, there is a low risk of erosion of the genetic diversity of wild species growing in natural environments.

Further, gene flow, the transfer of genes from one population to another may lead to unwanted effects for weed management and the environment. It may enable resistance genes to move between HR and non-HR varieties and hence pollute a crop which is considered GM-free. HR-genes may be stacked from years of cross-pollination of HRCs, which may create problems to the farmer in controlling volunteer crops in the field. Multiple herbicide-resistant volunteer oilseed rape has been observed in Canada where oilseed rape with resistance to different herbicides was grown on neighbouring fields (Hall et al. 2000). Identification of successful hybridization between canola (Brassica napus) and wild mustard (Sinapsis arvensis) and between canola and wild radish (Raphanus raphanistrum) (Rieger et al., 2001) caused some alarm amongst environmentalists. Potential gene flow from HR rice (Orya sativa L.) to different weedy rice (O. Sativa f. spontanea) was also reported recently (Song et al., 2009). In addition, there has been a range of studies over the past 10- 15 years on gene flow between related species i.e. crop cultivars and their wild relatives (Table 2). 
Table 2. Out-crossing and gene flow within and between different crop plants and relatives. Out-crossing frequency $(\mathrm{OCF})$ is between closely situated plants. Isolation distance (ID) used in plant breeding. Gene flow is measured as potential $(\mathrm{P})$ or actual (A) gene flow. (Source: Madsen \& Jensen 1998)

\begin{tabular}{|c|c|c|c|c|c|c|c|}
\hline $\begin{array}{l}\text { Pollen } \\
\text { Donor }\end{array}$ & $\begin{array}{l}\text { Pollen } \\
\text { receiving } \\
\text { Species }\end{array}$ & OCF & Vector & $\begin{array}{l}\text { ID } \\
\text { (m) }\end{array}$ & $\begin{array}{l}\text { Exp. det. } \\
\text { Distance } \\
\text { (m) }\end{array}$ & $\begin{array}{c}\text { Frequency } \\
\text { at max } \\
\text { distance }\end{array}$ & $\begin{array}{c}\text { Gene } \\
\text { flow }\end{array}$ \\
\hline $\begin{array}{l}\text { Beta } \\
\text { vulgaris }\end{array}$ & B. maritima & high & wind & & 75 & $0.06-0.31 \%$ & A \\
\hline $\begin{array}{l}\text { Brassica } \\
\text { napus }\end{array}$ & $\begin{array}{l}\text { Brassica } \\
\text { napus }\end{array}$ & $22-36 \%$ & $\begin{array}{l}\text { bees } \\
\text { (wind) }\end{array}$ & 200 & 200 & $\begin{array}{l}0.008- \\
0.017 \%\end{array}$ & $\mathrm{P}$ \\
\hline $\begin{array}{l}\text { Brassica } \\
\text { napus }\end{array}$ & B. rapa & $13 \%$ & bees & 500 & & & A \\
\hline $\begin{array}{l}\text { Brassica } \\
\text { napus }\end{array}$ & B. juncea & some & bees & 800 & & & \\
\hline $\begin{array}{l}\text { Brassica } \\
\text { napus }\end{array}$ & B. oleracea & some & bees & 800 & & & \\
\hline $\begin{array}{l}\text { Solanum } \\
\text { tuberosum }\end{array}$ & $\begin{array}{l}\text { S. } \\
\text { tuberosum }\end{array}$ & low & bees & & 4.5 & $0.05 \%$ & A \\
\hline $\begin{array}{l}\text { Pisum } \\
\text { sativum }\end{array}$ & P. sativum & minimal & insects & 1 & & & \\
\hline $\begin{array}{l}\text { Hordeum } \\
\text { vulgare }\end{array}$ & H. vulgare & $0.5-5 \%$ & wind & & & & \\
\hline $\begin{array}{l}\text { Triticum } \\
\text { aestivum }\end{array}$ & T. aestivum & $<3 \%$ & wind & & & & \\
\hline $\begin{array}{l}\text { Secale } \\
\text { cereale }\end{array}$ & S. cereale & $55-100 \%$ & wind & & 700 & $10 \%$ & $\mathrm{P}$ \\
\hline $\begin{array}{l}\text { Cucurbita } \\
\text { pepo }\end{array}$ & C. texana & high & bees & 400 & 1300 & 0 & A \\
\hline $\begin{array}{l}\text { Oryza } \\
\text { sativa }\end{array}$ & $\begin{array}{l}\text { O. sativa } \\
\text { (red rice) }\end{array}$ & $1-52 \%$ & & & & & \\
\hline $\begin{array}{l}\text { Sorghum } \\
\text { bicolor }\end{array}$ & $\begin{array}{l}\text { S. halepense } \\
\text { (Johnsongra } \\
\text { ss) }\end{array}$ & $10-15 \%$ & wind & $\begin{array}{l}200- \\
400 \mathrm{~m}\end{array}$ & $\begin{array}{l}\text { hand- } \\
\text { crosses }\end{array}$ & $11 \%$ & A \\
\hline $\begin{array}{l}\text { Helianthus } \\
\text { annuus }\end{array}$ & H. annuus & $27 \%$ & insects & 88 & 1000 & $2 \%$ & A \\
\hline Zea maiys & Z. mexicana & $95 \%$ & wind & $\begin{array}{l}180- \\
750\end{array}$ & & & A \\
\hline $\begin{array}{l}\text { Lupinus } \\
\text { albus }\end{array}$ & $\begin{array}{l}\text { L. } \\
\text { angustifolius }\end{array}$ & $8.4 \%$ & bees & 200 & 37.5 & $0.04 \%$ & A \\
\hline
\end{tabular}


Many studies focused on hybridization within and between crops and wild relatives. According to data given in Table 2, there are many examples showing high out-crossing percentages between closely related cultivated crop species as well as between cultivated crop species and their wild relatives.

In case of the herbicide resistant genes, which are transferred to their wild relatives, these relatives could then develop herbicide resistance to become "super-weeds". Subsequently, the use of herbicide becomes redundant. In this situation, farmers need to use more herbicide, or to change the herbicide to one in which there is no resistance. However, the past has repeatedly shown that cropping system diversity is the pillar of sustainable agriculture. If the large-scale cultivation of HR crops adheres to this fundamental principle, it is possible to avoid the intense selection pressure for weed resistance and consequently, greater herbicide use in future to control HR weed biotypes (Beckie et al., 2006).

\section{Alternatives to Herbicide Resistant Crops}

It is worthwhile to find possible alternative technologies, either existing or in development, which are capable in replacing HRCs. Applications of herbicides and tillage practices have been the oldest way of controlling weeds. Although new herbicides are being developed, unlike broad-spectrum herbicides, glyphosate and glufosinate, the new herbicides, are unlikely to influence the use of HRCs significantly.

Conventional approaches to bio-control of weeds had little impact on weed management (Duke et al., 2003). Research is underway to improve bio-control agents with transgenes (Duke, 2003; Duke et al., 2003). However, this technology has considerably more environmental risk than HRCs. Research is also underway to make crops more allelopathic with transgene technology, expecting that herbicide use would be substantially reduced with such varieties (Duke et al., 2002; Duke, 2003). There is concern that introgression of transgenes for this type of trait into wild species could increase fitness in their natural ecosystems, with unpredictable consequences.

Another alternative is to promote crop cultivars/varieties which are being cultivated processing herbicide tolerance or herbicide 
resistance. A study conducted by Weerakoon et al., (2013a) revealed that there were ten inbred cultivated rice varieties and three traditionally cultivated rice varieties in Sri Lanka processing natural resistance to glyphosate.

\section{Suitability of Herbicide Resistant Crops for Sri Lanka}

Sri Lanka is a country with an agriculture based economy, and the introduction of HRCs and their impacts is an important issue. The farmer's main concern is to produce as much crop as possible at the lowest cost to sell at the highest price. For many, this is an uphill task, and many find it hard to grow enough crops to live on. In recent years, Sri Lankan food imports have gone up, with even basic crops like rice, potato and green gram have to be imported to meet consumer demands.

In most of the developed world, the major crop species have been introduced from elsewhere, but many developing countries like Sri Lanka, India etc. are the centres of origin and centres of diversity of crops grown in these countries. Therefore, the risk of introducing alien genes into wild relatives could be somewhat higher in such countries (Kumar et al., 2008). In these circumstances bio-pollution is possible which can destroy the original genetic diversity. Sri Lanka has a varied climate and topography, which has given rise to rich species diversity, believed to be the highest in Asia, in terms of unit land area. This is especially relevant for mammals, reptiles, amphibians and flowering plants. The biological wealth is distributed within a multitude of systems that have been broadly categorized as coastal and marine, forest, wetland and cultivated areas. Sri Lanka is also identified as one of the global biodiversity hotspots indicating its significance in biological wealth and threats to the biological wealth (National Bio-safety Framework of Sri Lanka, 2005).

Sri Lanka signed the Cartagena Protocol on Bio-safety on 24 May 2000, during the fifth meeting of the Conference of Parties to the Convention on Biological Diversity in Nairobi, Kenya. The country ratified Cartagena Protocol on 28 April 2004 and consequently the Protocol has entered into force in the country on July 2004. As a result the national bio-safety framework was established. The overall objective of Sri Lanka's national bio-safety framework is to ensure that the risks likely to be caused by modern biotechnology 
and its products will be minimized and biodiversity, human health and environment will be protected in a maximum way regulating the trans boundary movements through formulation of relevant policies, regulations, technical guidelines and establishment of management bodies and supervisory mechanisms. Thus, bio safety framework is based on a precautionary approach. As a consequence, there are strict regulations and management of GMOs including GM crops imported to Sri Lanka and produced within the country (National Bio-safety Framework of Sri Lanka, 2005). Recently, bio-safety act of Sri Lanka has been discussed in many fora to be finalized as a parliament act. It has much concerns and restrictions on introducing transgenic plants/animals and transgenic products to Sri Lanka.

The evidences reviewed by Raney (2006) suggest that farmers in developing countries can benefit from GM crops. A considerably high level of institutional capacity at the national level is necessary to ensure that farmers have access to suitable newly developed seeds or other plant material on competitive terms. Up to a certain amount of national level research and regulatory capacity, effective IPR management and input supply systems are essential. The financial outcomes so far propose that farmers in developing countries can benefit from transgenic crops. However, for the underprivileged farmers in developing countries, where institutional conditions are poor, the benefits they gain from transgenic crops still remain questionable. Sri Lanka is a developing country with a limited national institutional capacity which lacks the necessary financial resources and is limited in the scientific infrastructure needed to develop their own biotechnology programs for the crops that are important to feed our people.

Further, the additional expenses of GM seeds compared to conventional/traditional varieties are significantly high. Therefore, at present, we are not in a position to rely on GM crops, including transgenic and non-transgenic HRCs to meet the national food demand. In addition to the poor economy in the country, environment and food safety regulations, social, health and environmental issues also contribute for GM crop restrictions.

About $90 \%$ of rice production and consumption worldwide occurs in Asia. In Sri Lanka, rice is the main food crop growing on 0.77 million ha in all agro climatic zones (Department of Agriculture, 2003). There are major concerns in attempting to introduce HRrice to Asian countries, although HR-rice has the potential to 
improve the efficiency of weed management (Kumar et al., 2008). So far three HR systems have been developed in rice: imidazolinone-, glufosinate-, and glyphosate-resistant varieties (Gealy et al., 2003). However, a recent survey in India exposed the many risks of introducing HR rice to South East Asian countries. The greatest risk in the commercialization of HR-rice is the potential for transfer of the gene conferring the HR trait to relative wild relatives. This could lead to increased weediness or invasiveness. Gene transfer between cultivated and wild or weedy rice is known to occur (Song et al., 2009). In addition to gene flow from HR-rice to its wild and weedy relatives, gene flow from HR rice to conventional rice cultivars is another risk. The likelihood of such gene transfer is high in Sri Lanka and India, where cultivated rice and its relatives are symmetrically distributed and their flowering times overlap. Such gene flow can impact crop invasiveness, fitness of wild species, and the loss of native biodiversity. Additionally, HR rice may contribute to the problems of crop volunteers and evolution of herbicide resistance (Kumar et al., 2008).

At present, there are only two HR weeds reported in Sri Lanka. It was reported that the weed Barnyardgrass (Echinochloa crus-galli) a monocot of the family Poaceae, first evolved resistance to Group $\mathrm{C} 2 / 7$ herbicides in 1997 and infests rice (Ntanos et al., 2000). Group $\mathrm{C} 2 / 7$ herbicides are known as Ureas and amides (Inhibition of photosynthesis at photosystem II). Research has shown this species resistant to propanil and they may be crossresistant to other Group $\mathrm{C} 2 / 7$ herbicides. The second weed Sumatran Fleabane (Conyza sumatrensis) is a dicot weed in the family Asteraceae and first evolved resistance to Group D/22 herbicides in 1998 and infests tea. Group D/22 herbicides are known as Bipyridiliums (Photosystem-I-electron diversion). Research has shown that these particular species is resistant to paraquat and they may be cross-resistant to other Group D/22 herbicides (Heap, 2007). The latest addition to HR weeds is weedy rice (Oryza sativa $f$ spontanea), which was first reported in Sri Lanka in 1997 from the Ampara district (Marambe, 2009; Abeysekera et al., 2010). This has become a major threat to Sri Lanka's paddy cultivation showing resistance to glyphosate (Abeysekera et al., 2010). Thus, existing scientific literature related to benefits and risk of HRCs is limited and further detailed studies are needed to fully assess the potential beneficial and adverse consequences of widespread adaptation of HRCs in Sri Lanka. 
Sustainable agriculture has given higher productivity and yields in developing countries (Pretty \& Hine, 2000). According to IFOAM (2003), land area under organic management in Asia was the largest in China (301,295 ha) followed by Indonesia (40,000 ha), Sri Lanka $(15,215$ ha), Japan $(5,083$ ha), Thailand $(3,429$ ha), Pakistan (2,009), Taiwan (1,092 ha), Republic of Korea (902 ha), and Malaysia (131 ha). Sustainable agricultural practices tend to reduce soil erosion, as well as improve soil physical structure and water-holding capacity. Soil fertility is also maintained by various sustainable agriculture practices. Further, sustainable agriculture promotes agricultural biodiversity, which is crucial for food security and rural livelihood. Organic farming can also support much greater biodiversity (Institute of Science in Society, 2004). A similar sustainable strategy could also be adopted to utilize HRCs in Sri Lanka in future, i.e. cultivation of HRCs and non-HRCs in rotation along with proper herbicide combinations to minimize the gene-transfer from HRCs to their wild relatives to prevent evolving volunteer weeds.

\section{Conclusions}

The review of the literature on the HRCs led to the following conclusions.

- HRCs have a great potential in the simplification of weed management. If proper care is exercised in introducing HRCs, they may be beneficial to the environment by enabling no-till systems, thus reducing erosion or allowing for later weed control, which may increase bio-diversity in the field. However, it must be emphasized that the risk from HRCs should be carefully evaluated prior to releasing the HRC into a cropping system, especially when the HRCs possess weedy characters or may outcross with related weeds. If this is the case, and the HRC is grown commercially, then precautions need to be taken, similar to the management strategies adopted to prevent the development of naturally-resistant weeds. Furthermore, precautions must, in particular, be taken before release into the areas of genetic origin of a particular species.

- There is a need of extensive study on the potential issues related to the introduction of HRCs to Sri Lanka. A considerable portion of the National Budget of Sri Lanka is 
devoted to the import of food to meet increasing consumer demands. Introduction of transgenic and other genetically modified crops and their impacts have become an important issue. The low-cost crop productivity and selling at the highest price would become another major concern. Therefore, there are many doubts about the benefit of such crops to farmers which are needed to be rectified.

- The country's higher biological diversity may have a higher risk of introducing alien genes through HRCs. This can lead to "bio-pollution" in Sri Lanka depleting native original genetic diversity and increase the number of HR weeds.

Sri Lanka has a limited national level institutional capacity and most of such institutions have limited financial resources and the scientific infrastructure which is required to produce the new crop cultivars using our own biotechnology programs. The capacity should be built to address the issues to assess the potential beneficial and adverse consequences of introduction of HRCs to Sri Lanka.

\section{References}

Abeysekara, A. S. K., Nugaliyadda, L., Herath, H. M. S., Wickrame, U. B. \& Iqbal, Y. B. (2010). Weedy Rice: a threat to direct seeded rice cultivation in Sri Lanka. Rice Congress 2010, PGRC, Gannoruwa, Pp 17-18.

Anderson, T. (2001). Biotech soybean seed helps growers produce safe and profitable crops. American Soybean Association. Available online at http:/ /www.monsanto.co.uk/news/ukshowlib.phtml? uid=5063, (accessed 15th May 2011).

Annou, M., Thomsen, M., Wailes, E. \& Garner, G. L. (2001). Implications of Rice Biotechnology on optimal rice crop rotation in the Mississippi River Delta Region. Paper presented at the Southern Agricultural Economics Association, Annual Meetings, Fort Worth, Texas, U.S.A. January $27-31$.

Ashfaq-Farooqui M, Rao, A. V., Jayasree, T. \& Sadanandam A (1997). Induction of atrazine resistance and somatic 
embryogenesis in Solanum melongena. Theoretical and Applied Genetics 95: 702-705.

Ahmad, I., Day, J. P., MacDonald, M. V. \& Ingram, D. S. (1991). Haploid culture and UV Mutagenesis in rapid-cycling Brassica napus for the generation of resistance to chlorsulfuron and Altaernaria brassicola. Annals of Botany 67: 521-525.

Beckie, H. J., Harker, K. N., Hall, L. M., Warwick, S. I., Légère, A., Sikkema, P. H., Clayton, G.W., Thomas, A. G. , Leeson, J.Y., Séguin-Swartz, G. \& Simard, M.- J. (2006). A decade of herbicide-resistant crops in Canada. Canadian Journal of Plant Science. 12431264.

Benbrook C. M. 2001. Trouble times amid commercial success for Roundup Ready soybeans. AgBioTech InfoNet technical paper number 4. May 3, 2001, $6 \mathrm{Pp}$

Bonny, S. (2009). Issues, impacts, and prospects of the first transgenic crops tolerant to a herbicide. Proceedings of International Association of Agricultural Economics Conference, Beijing, China, August 16-22, Pp. 1-13.

Brookes G \& Barfoot P (2007). Global impact of biotech crops: Socio-economic and environmental effects, 1996-2006. AgBioForum, 11: 21-38. Available on the World Wide Web at: www.agbioforum.org (accessed 10 $10^{\text {th }}$ April 2011).

Caretto, S., Giadina, M. C., Nicolodi, C. \& Mariotti, D. (1994). Chlorsulfuron resistance in Daucus carota cell lines and plants: Involvement of gene amplification. Theoretical and Applied Genetics 88: 520-524.

Carpenter, J. E. \& Gianessi, L.P. 2001. Agricultural biotechnology: Updated benefit estimates. Report from the National Center for Food and Agricultural Policy. Washington DC, 46.

Department of Agriculture, Sri Lanka (2003). Available online at: http://www.knowledgebank.irri.org/regionalsites/srila nka. (accessed 15th May 2011). 
Devine, M. D. \& Buth, J. L. (2001). Advantages of genetically modified canola: a Canadian perspective. Proceedings of Brighton Crop Prot Conf-Weeds, BCPC, Farnham, Surrey, UK, Pp. 367-372.

Devine, M. D. (2005). Why are there not more herbicide-tolerant crops? Pest Management Science 61: 312-317.

Duke, S. (1996). Herbicide resistant crops: Agricultural, Environmental, Economic, Regulatory and Technical Aspects. CRC Lewis Publishurs, Boco Raton.

Duke, S. O., Scheffler, B. E., Dayan, F. E. \& Dyer, W. E. (2002). Genetic engineering crops for improved weed management traits. Proceedings of ACS Symposium Series No. 829, American Chemical Society, Washington, DC, Pp. 52-66.

Duke, S. O. (2003). Weeding with transgenes. Trends in Biotechnology 21: 192-195.

Duke, S. O., Scheffler, B. E., Boyette, C. D., Lydon, J. \& Olivia, A. (2003). Herbicides: Biotechnology for control of weeds. In: J. R. Plimmer, D. W. Gammon and N. N. Ragsdale, (Eds), Encyclopedia of agrochemicals (pp. 733-744), $2^{\text {nd }}$ Edition; John Wiley \& Sons, New York.

Duke, S. O. (2005). Taking stock of herbicide-resistant crops ten years after introduction. Pest Management Science 61: 211-218.

FAO. 2001. Draft of guidelines for assessment of ecological hazards of herbicide- and insect-resistant crops. Plant Protection Division, Rome. (In collaboration with Kathrine H. Madsen, Valverde, Bernal E. \& Streibig, Jens C., of the Royal Veterinary and Agricultural University, Denmark). 18 Pp.

Gealy, D. R \& Dilday, R.H. 1997. Biology of red rice (Oryza sativa L.) accessions and their susceptibility to glufosinate and other herbicides. Weed Sci. Soc. Am. Abstr. 37: 34. 
Gealy, D. R., Mitten, D. H. \& Rutger, J. N. (2003). Gene flow between red rice (Oryza sativa) and herbicide-resistant rice $(O$. sativa): Implications for weed management. Weed Technology 17: 627-645.

Green, J. M. \& Owen M. D. K. 2011. Herbicide-Resistant Crops: Utilities and Limitations for Herbicide-Resistant Weed Management. Journal of Agric Food Chem. 59(11): 5819-5829.

Hall, J. C., Donnelly-Vanderloo, M. J. \& Hume, D. J. (1996). Triazine-resistant crops: the agronomic impact and physiological consequences of chloroplast mutation. In: S. O. Duke (Ed), Herbicide-resistant crops: agricultural, environmental, economic, regulator, and technical aspects (pp. 107-126), CRC Press, Boca Raton, FL.

Hall, L., Topinka, K., Huffman, J., Davis, L. \& Good, A. (2000). Pollen flow between herbicide-resistant Brassica napus is the cause of multiple-resistant $B$. napus volunteers. Weed Science 48: 688-694.

Heap, I. M. (2007). International Survey of Herbicide Resistant Weeds. Weed Science Society of America. Available online at: http://www.weedscience.org/In.asp. (accessed 11th March 2011).

IFOAM (2003): Organic and Like-Minded Movements in Africa. International Federation of Organic Agriculture Movements (IFOAM), Bonn, pp.102-108.

Institute of Science in Society (2004). ISP to FAO: GM Crops not the Answer. ISIS Science Society Sustainability, ISP Press Release 27/05/2004.

Jain, M., Bhatnagar, R. K. \& Sarin, N. B. (1999). Isolation and biochemical diagnosis of cell lines of groundnut (Arachis hypogaea L.) selected on glyphosate. Pesticide. Science 55: 843-849.

James, C. (2003). Preview: Global status of commercialized transgenic crops, ISAAA Briefs No.30. 
Kumar, V., Bellinder, R. R., Brainard, D. C., Malik, R. K. \& Gupta, R. K. (2008). Risks of herbicide-resistant rice in India: A review. Crop Protection 27: 320-329.

Madsen, K. H. \& Jensen, J. E. (1998). Meeting and training on risk analysis of HRCs and exotic plants. Course material for the UN Food and Agricultural Organization (FAO) in Piracicaba, Brazil 19-22 May 1998.

Madsen, K. H., Poulsen, G. S., Fredshavn, J. R., Jensen, J. E., Steen, P. \& Streibig, J. C. 1998. A method to study competitive ability of hybrids between seabeet (Beta vulgaris ssp. maritima) and transgenic glyphosate tolerant sugarbeet (Beta vulgaris ssp. vulgaris). Acta Agriculturæ Scandinavica, Section B, Soil and Plant Science 48: 170-74.

Madsen, K. H., Sandøe, P. \& Lassen, J. 2002a. Genetically modified crops: A US farmer's versus an EU citizen's point of view. Acta Agriculturae Scandinavica (in press).

Madsen, K. H., Valverde, B. E. \& Jensen, J. E. 2002b. Risk assessment of herbicide resistant crops: A Latin American perspective using rice (Oryza sativa) as a model. Weed Tech. 16 (1), 215-223.

Marambe, B. (2009). Weedy rice: Evolution, Threats and Management. Tropical Agriculturist, 157: 43-64.

McCabe P. F, Cselpo A, Timmons, A. M. \& Dix, P. J. (1990). Selection of chloroplast mutants. In: J. W. Pollard and J. M. Walker (Eds), Methods in Molecular Biology (pp. 467-675), The Humana Press, Totowa NJ.

Motavalli, P. P., Kremer, R. J., Fang, M. \& Means, N. E. (2004). Impact of genetically modified crops and their management on soil microbially mediated plant nutrient transformetions. Journal of Environment Quality 33: 816-824.

Mulwa, R. M. S. \& Mwanza, L. M. (2006). Biotechnology approaches to developing herbicide tolerance/ 
selectivity in crops. African Journal of Biotechnology 5: 396-404.

Murata, M., Ryu, J. H., Caretto, S., Rao, D., Song, H. S. \& Widholm, J. M. (1998). Stability and culture limitations of gene amplification in glyphosate resistant carrot cell lines. Journal of Plant Physiology 152: $112-117$.

National Bio-safety Framework of Sri Lanka (2005). Ministry of Environment and Natural Resources, Colombo, Sri Lanka. Pp. 1-68.

Ntanos, D. A., S. D. Koutroubas, \& C. Mavrotas (2000). Barnyardgrass (Echinochloa crus-galli) control in waterseeded rice (Oryza sativa) with cyhalofop. Weed Technology 14:383-388.

Olofdotter, M., Valverde, B.E. \& Madsen, K.H. 2000. Herbicide resistant rice (Oryza sativa L.) in a global perspective: Implications for weed management. Annals of Applied Biology 137, 279-295.

Padgette, S. R., Re, D. B., Barry, G. F., Eichholtz, D. E., Delannay, X., Fuchs, R. L., Kishore, G. M. \& Fraley, R. T. (1996). New weed control opportunities: development of soybeans with a Roundup Ready gene. In: S. O. Duke (Ed), Herbicide-resistant crops: agricultural, environmental, economic, regulator, and technical aspects (pp. 53-84), CRC Press, Boca Raton, FL.

Pretty, J. N. and Hine, R. (2000). The promising spread of sustainable agriculture in Asia. Natural Resources Forum 24: 107-126

Raney, T. (2006). Economic impact of transgenic crops in developing countries. Current Opinion in Biotechnology 17(2): 1-5.

Reddy, K. N., Duke, S. O. \& Rimando, A. M. (2004). Aminomethylphosphonic acid, a metabolite of glyphosate, causes injury in glyphosate-treated, glyphosate-resistant soybean. Journal of Agricultural and Food Chemistry 52: 5139-5143. 
Reiger, M. A., Potter, T. C., Preston, C. \& Poeles, S. B. (2001). Hybridization between Brassica napus L. and Raphanus raphanistrum L. under agronomic field conditions. Theoretical and Applied Genetics 103: 555560 .

Sandhu, S. S, Bastos C. R, Azini L. E \& Neto A. T, Colombo C ( 2002). RAPD analysis of herbicide-resistant Brazilian rice lines produced via Mutagenesis. Genetics and Molecular Research 1: 359-370.

Senior, I. J. \& Bavage, A. D. (2003). Comparison of genetically modified and conventially derived herbicide tolerance in oilseed rape: A case study. Euphytica 132: 217-226.

Shaner, D.I. (2000). The impact of glyphosate-tolarant crops on the use of other herbicide sand on resistance management. Pest Management Science 56: 320-326.

Si, P., Buirchell, B. \& Sweetingham, M. (2009). Improved metrabuzin tolerance in narrow-leafed lupin (Lupinus angustifolius L.) by induced mutation and field selection. Field Crops Research 113: 282-286.

Song, X., Liu, L. Wang, Z. \& Qiang, S. (2009). Potential gene flow from transgenic rice (Oryza sativa L.) to different weedy rice (Oryza sativa f. spontanea) accessions based on reproductive compatibility. Pest Management Science 65: 862-869.

Somers D. A. (1996). Aryloxyphenoxypropionate- and cyclohexanedione-resistant crops. Herbicide-Resistant Crops: Agricultural, Environmental, Economic, Regulatory, and Technical Aspects; Duke S. O., editor. , Ed.; CRC Press and Lewis: Boca Raton, FL, pp 175188.

Stalker, D. M., Kiser, J. A., Baldwin, G., Coulombe, B. \& Houck, C. M. (1996). Cotton weed control using the BXN system. In: S. O. Dule (Ed), Herbicide-resistant crops: agricultural, environmental, economic, regulator, and technical aspects (pp. 93-105), CRC Press, Boca Raton, FL. 
Swanton, C. J., Shrestha, A., Chandler, K. \& Deen, W. 2000. An economic assessment of weed control strategies in notill glyphosate-resistant soybean (Glycine max). Weed Tech. 14: 755-763.

Tan, S., Evans, R. R., Dahmer, M. L., Singh, B. K. \& Shaner, D. L. (2005). Imidazoline-tolerant crops: history, current status and future. Pest Management Science 61: 246257.

Thomas, B. R. \& Pratt, D. (1982). Isolation of paraquat-tolerant mutants from tomato cell cultures. Theoretical and Applied Genetics 63: 169-176.

Tsaftaris A (1996). The development of herbicide-tolerant transgenic crops. Field Crops Research 45: 115-123.

Toldi, O., Toth, S., Oreifig, A. S., Kiss, E., \& Jenes, B. (2000). Production of phosphinothricin-tolerant rice (Oryza sativa L.) through the application of phosphinothricin as a growth regulator. Plant Cell Reports 19: 12261231 .

Tuinstra M. R. (2008). Al-Khatib K.Acetolactate synthase herbicide resistant sorghum; U. S. Patent Appl. 2008/0216187 A1,

Venkataiah, P., Christopher, T. \& Karampuri, S. (2005). Selection of atrazineresistant plants by in vitro Mutagenesis in pepper (Capsicum annuum). Plant Cell, Tissue and Organ Culture 83: 75-82.

Warabi, E., Usui, K., Tanaka, Y. \& Matsumoto, H. (2001). Resistance of a soybean cell line to oxyfluorfen by overproduction of mitochondrial protoporphyrinogen oxidase. Pesticide Management Science 57: 743-748.

Wilcut, J. W., Coble, H. D., York, A. C \& Monks, D. W. 1996. The niche for herbicide-resistant crops in U.S. agriculture. In Duke, S.O., ed., Herbicide-resistant crops, agricultural, environmental, economic, regulatory, and technical aspects. CRC Press Inc., Boca Raton, Florida, USA. pp. 213-230. 
Marambe, B. 2009. Weedy rice: Evolution, Threats and Management. Tropical Agriculturist, 157: 43-64.

Weerakoon, S. R., Somaratne, S., Wijeratne, R. G. D. \& Ekanayaka, E. M. S. I. (2013a). Natural Herbicide Resistance (HR) to Broad-spectrum Herbicide, Glyphosate among Traditional and Inbred-cultivated Rice (Oryza sativa L.) varieties in Sri Lanka. Pakistan Journal of Biological Sciences. 16 (16): 796-803.

Weerakoon, S, R,. Wijeratne, R. G. D. \& Somaratne, S. (2013b). Studies on Natural Herbicide Resistance (HR) among traditional and developed rice (Oryza sativa L.) varieties cultivated in Sri Lanka and inducing HR with Chemical mutagens, $\mathrm{NaN}_{3}$ and EMS. The $4^{\text {th }}$ Tropical Weed Science Conference, Chiang Mai, Thailand. 23 ${ }^{\text {rd }}$ to $2^{\text {th }}$ January, 2013. pp. 27. 